\title{
Significant Factors Influencing Quality Assurance Practices in Small and Medium-Sized Construction Projects in South Africa
}

\author{
Kgashane Stephen Nyakala1, Thinandavha Thomas Munyai ${ }^{1}$, Jan-Harm Pretorius ${ }^{2}$, Andre Vermeulen ${ }^{2}$ \\ 1Tshwane University of Technology, South Africa \\ ${ }^{2}$ University of Johannesburg, South Africa \\ nyakalaks@tut.ac.za
}

\begin{abstract}
Although implementing quality assurance (QA) processes in construction play an important role in the South African economy has been acknowledged. However, constructions SMEs are faced with difficulties in improving rural road infrastructure and high-quality roads. Additionally, past research has failed to reach consensus on the construction process and socioeconomic settings in previously disadvantaged areas in South Africa, including the factors influencing negatively the performance of such factors. This research examines what factors facilitate or inhibit the success of construction SMEs and what actions can be taken to being distressed construction SMEs under control. The study adopted a quantitative research approach in which a three-section questionnaire was administered to 160 purposively chosen road- building experts in a South African construction SMEs. The questionnaire was structured into three parts, which sought the participants' profile, identified the quality assurance practices (QAPs) incorporated in the construction SMEs' road building programmes, and identified the factors that negatively influence the implementation of QA processes. Data was analysed using the Statistical Package for the Social Sciences (SPSS) version 22. Furthermore, to determine the reliability of the various constructs, mean scores, descriptive statistics and standard deviations were obtained. The empirical findings established eight QAPs that were reliable and valid for implementation processes that can control or minimise their causes of poor quality in projects undertaken by construction SMEs, level of skill acquisition; project planning and control techniques; project construction design; process implementation and process improvement; financial management; organisational structures; involvement of people; and quality standards and measurements. The eight factors attained high Cronbach Alpha values above the recommended 0.70 which indicates high internal consistencies among the sub-scales. Findings from this study should be useful to managers in similar environments may use the results of this study as either diagnostic tools or as a reference benchmark for strategic interventions in solving construction projects related problems. Furthermore, the researchers also recommend that these practices are for quality assurance in construction projects undertaken by SMEs in South Africa.
\end{abstract}

Keywords: South Africa, SME construction projects, quality assurance practice, road construction

\section{Introduction}

The construction industry is considered a key industry in any economy. The construction sector in Southern Africa itself is a challenging field of work because there are many multifaceted responsibilities and operational procedures (Mofokeng \& Thwala, 2012: 712; Windapo \& Cattel, 2013; George, 2016:24). According to the annual report on South African SME construction projects, there existed 30.1\% to 39.4 $\%$ inefficiency, poor quality of rural road building and lack of construction process planning amongst SMEs contractors (Statistics South Africa, 2017). In addition, improper implementation of rural road construction projects causes considerable problems for contractors (Vermeulen et al., 2018). Construction organisations display distinctive characteristics, combined with the varying demands of the industry's stakeholders, which includes uniting varied investors, clients, consulting professions and contractual engagements (Badu \& Owusu-Manu, 2011:271; Construction Industry Development Board (CIDB), 2012). Construction SMEs can be described as those SMEs which work on construction projects, comprising some components of the design and control of construction works as well as the quantity of building materials, tools, equipment, plant, transport and other services (Rumane, 2011). The South African local government is obliged to render basic services for the people, with a special focus on the provision of roads in the local communities they serve. Adequate road contributes immensely to the economic growth, development and redistribution (Statistics South Africa, 2017). Roads network infrastructure delivery should ensure and provide good outcomes for the public (Nyakala et al., 2017:636). Total quality management research in the construction process has revealed that improving staff performance, customer satisfaction and confidence in the organisation's products/services are beneficial to all construction and business organisations (Arditi \& Gunaydin, 1997). 
Understanding the relationship between process quality and product quality could consequently be useful in cultivating the QAPs that can reduce poor quality and cost overruns in construction projects. It is imperative to discover this relationship, mainly because of the great impact of the construction sector on the economy of a country. Fang and Wu (2013:139) note that good transport infrastructure has a positive influence mostly on the life of the rural people, and supports the establishment of effective co-ordinating constructions throughout government to promote efficiency in road service delivery. To provide quality service delivery, all employees in a road network infrastructure, therefore, need to understand project management techniques and tools, (Basu, 2004). The specific question to be answered here is: "What aspects expedite the practice of QA processes in road construction projects? The present paper follows preceding efforts to understand the processes of improving the quality of the construction projects (Ahadzie et al., 2007:806). There is also much agreement concerning the benefits expected from effective contractor development, encompassing global attractiveness, sustainable industry growth, good environmental management and socio-economic development of the developing countries (Van Wyk, 2003).

It is thus important that QA processes should be practiced in the South African construction industry. Seemingly, lessons learned have possibilities to enhance the image of the QA process implementation (Vermeulen et al., 2018:1). The aims of this paper are to examine key factors that influence QAPs in construction SMEs and uncover the collective working practices that can control or minimise causation characteristics. The result is not only useful to participants in the QA processes implementation within the construction industry but also to societies in other countries, and the rest of the world. In order to understand the implementation process of QAPs in construction SMEs, it is important to introduce the present theory on the quality management concepts included in this study. The current theory focuses on the overall concepts on the quality management in the construction project and project management; structures and QA involves establishing project related policies, procedures, standards, training, guidelines and systems necessary to produce quality. The improvement and prioritisation of rural roads networks play a vital role in developing countries to improve the socioeconomic conditions experienced by societies.

However, a wide range of challenges is encountered by SMEs in the construction industry when dealing with construction projects, and as a result, poor quality and poor performance of work is prevalent. South Africa is mostly characterised by the failure of small businesses' entrepreneurial capacity, which is largely characterised by low levels of entrepreneurial education (Mofokeng \& Thwala, 2012). The reason for this is that there is incomplete accessibility of road network infrastructure and high volume roads in rural connectivity, crisis management, and liveability (Fang \& Wu, 2013; Nyakala et al., 2017:640). It is against this background that this study was introduced to examine the factors that influence QAPs in construction projects. In order to achieve the aim of this study, two objectives were set out: to examine the QAPs incorporated in the rural road infrastructure of construction SMEs, and to determine the factors that positively influence the practice of construction SMEs. Identifying such factors will assist management to the success of QAPs are put in place to deal with such matters, which, in the long term, will cause a huge decrease in misfortunes that occur on construction SMEs.

Quality Assurance in SMEs: The literature review identified a number of quality assurance in SMEs designed to maximize employee performance in facilitating a business's strategic objectives (Basu, 2004; Freeman-Bell \& Balkwill, 1996; Aziz \& Abdel-Hakam, 2016; Panuwatwanich \& Nguyen, 2017). Various researchers on quality management approaches have agreed that unless SME contractors play an active role and take the lead to improve productivity management in the civil construction industry, efforts and gains made by individuals and departments will be short-lived (Arditi \& Gunaydin, 1997; Basu, 2004; Bierman, et al., 2013). As Mofokeng and Thwala (2012:713) mention, leadership can influence project success by establishing an environment, where project teams contribute towards success. In South Africa, project managers and project consultants are responsible for the overall construction success related to delivering infrastructure projects within the approved costs and time as well as the necessary quality and supervision. The above proposed broad view of project success also stresses the necessity for a joint performance assessment between project participants. As indicated earlier, quality cannot be seen by SMEs as an expensive process, an expensive product, or time-consuming but can improve their competitive capabilities in the marketplace (Kruger et al., 2014).

Level of Skill Acquisition Process: Mofokeng \& Thwala (2012:722) postulated that, the construction organisations needed to spearhead the capacitation of employees through the process of skill 
acquisition and facilitating employees' new skills. Aziz \& Gunaydin (1997) notes that opportunities for skills development in the construction industry had grown significantly and the main drivers were growth of businesses and infrastructures, environmental pressures and sustainability as well as management commitment. The literature review identified a number of quality management procedures in organisations designed to maximize employee performance in facilitating a business's strategic objectives (Basu, 2004; Freeman-Bell \& Balkwill, 1996; Aziz \& Abdel-Hakam, 2016; Panuwatwanich \& Nguyen, 2017). Mahmood et al. (2010) established that, for any built environment project to improve its competitive abilities in the construction industry, it should be able to determine the cost of poor quality and its impact on productivity and profitability. The success of construction projects is grounded on the individual competencies of site managers or project managers responsible for the execution process (Fotopoulos \& Psomas, 2009). Vermeulen et al. (2018:2) have clarified the main contributors of South African construction project participants as the designer or architect, the client, the project/construction manager and the contractors, which are then extended with many sub-teams with their own leaders who perform different functions.

Project Planning and Control Techniques: Successful implementation of QA developments necessitate actual planning and control practices, operations and review as well as stakeholder approval for business project activities (Nyakala et al., 2017:650). To effectively implement their QAPs, construction SMEs must meet their approved quality objectives and detailed requirements. Windapo \& Cattel (2013) state that for the successful execution of a project, effective planning is essential. A project manager holds the same responsibilities facilitates a formal system for record keeping, and provide work breakdown detail to all stakeholders (CIDB, 2012). Construction project management should include the design and execution of the infrastructure, the environmental impact of the job, the successful scheduling, budgeting, accessibility and delivery of building resources, inconvenience to the public affected by construction delays and bidding (Arditi \& Gunaydin, 1997; Rumane, 2011; Tshivhase \& Worku, 2012:62). Formal techniques of project management must be utilised by SME road contractors to enable citizens to have quality road networks and access to public services such as education, health facilities and the movement of labour between workplaces (Vermeulen et al., 2018:2). In addition to that, quality controls are required to prevent the deterioration of maintenance backlogs, and focus the efforts that the project manager has to spend on the daily control of the numerous activities of the project (Thorpe et al., 1996; Panuwatwanich \& Nguyen, 2017).

Project Construction Design: The context of project construction design within construction SMEs raised the question as to how senior project managers could adopt measurement tool in relation to QA processes and scope of work reporting on mistakes by the project team. Kerzner (2013) who state that the chief engineer is responsible for organizing technical personnel optimization of construction scheme, improving the technical measures as well as providing technical support for the effective cost control also supports this view. According to Kam and Hamid (2014:603), an example of an industry that heavily adopted the technology was manufacturing. As identified by computerized project management has been introduced in construction organisations such as Microsoft Project and Oracle Primavera further state that technical inspection of the construction progress with a high level of reliability was applicable in the early stages of a construction project. One major practical issue that has dominated the road construction projects for many years concerns the unpredictability in project construction designs creating complications when implementing processes of QA to the industry.

Process Implementation: The significance of applying proper management in dealing with the processes of QA in construction needed to be highlighted by the senior management team. The study analysed the project management tools that needed to be practiced in the local construction industry to enhance effective road construction projects. A recent study conducted by Aziz et al. (2016) found that having more experienced and capable construction managers, as well as skilled labourers, helped to enable the industry to develop at a faster rate either nationally or internationally. In the study, it was shown that the proper process implementation of quality assurance system helped organisations to better organise and synchronize their operations by documenting their procedures, clearly defining responsibilities and tasks among employees and subdivisions (Gotzamani \& Tsiotras, 2001). Project management also includes practical implementation (Olawale \& Sun, 2015), and it is widely accepted and well- documented that implementing QA processes presents a good opportunity for organisations that want to respond to the challenge. In the South African local government, such knowledge gaps are critically confronted by a lack of communication technologies. The minority of participants indicated that the local authority as very good 
rated 10.6 per cent of the SMEs projects.

Financial Management Skills: Financial management is a key factor influencing construction industry. The timely completion of road construction projects is considered one of the key factors referring to the project achievement as well as the quality and the safety (Aziz et al., 2016). In line with this, a cost-effective policy, competence and profitability are the main determinants of construction process planning, covering activities needed to deliver quality in work to meet the project requirements (Mahmood et al., 2010). Costs of restructuring the process must be controlled to eradicate the causes of poor quality and related preventive activities. The encompasses, for example, preparation, monitoring and analysis, project review, and quality improvement programs (Nyakala et al., 2017:650). Quality training and project control systems are essential for innovation and for technology advancement, and a standard of living improvement (Obare et al., 2016). The implementation of project control systems perpetuates them as engines through which the growth objectives of developing countries can be achieved (Ahadzie et al., 2007).

Quality Standards in the Construction Project: Quality standard scope signifies organisational performance through construction project management, quality policy, organisational structures and successful implementation of quality working practices by construction SMEs in the country (Vermeulen et al., 2018:3). The success of any construction organisation depends on how corporate strategies adopt continuous quality improvement practices (Kerzner, 2013). This will be supplemented in practical terms by implementing total quality strategies and empower employees in the construction project to identify opportunities and develop them more efficiently (Gardiner, 2005). During building operations, there must be quality control to ensure that the roads are constructed to expectations (Honnakker et al., 2010:954). Quality control verifies that processes are performed in a satisfactory manner (Kruger et al., 2014). Quality product procedures, product reliability, standards and dimensions are essential. These allow the contractor to evaluate and assess project processes against applicable standards, quality management tools and techniques, total quality management (TQM), cause-and-effect diagrams, policies and procedures (Gardiner, 2005).

Organisational Structure and Improvement Programs in SMEs: SME construction organisations are less able to deal with 'disclosures' in the global economy and as a result are mostly vulnerable. SME road construction projects need to be managed and controlled to allow goal setting for reconstruction, growth and improvement in the construction industry (Vermeulen et al., 2018). These gaps further include inadequate connectivity and mobility to reach out and open up new opportunities and improper physical infrastructure and economic developments. Enhancing competitiveness in the construction industry is measured to be a strategic prospect if it seems to be improving quality developments and incorporating engineering management principles and practices (Freeman-Bell \& Balkwill, 1996). Contractor development tools that meet challenges of globalisation are nowadays considered as techniques that frequently maintain the management of construction projects, multitudes of data, and tight deadlines that are characteristic of numerous industries and their extremely competitive settings (Badu \& Owusu-Manu, 2011).

Construction SMEs need computerised systems that follow the value chain in construction project delivery (Arditi \& Gunaydin, 1997). This supports the notion that quality must be built-in during design and are achieved through communication, development and improvement (Bierman et al., 2013; Olawale \& Sun, 2015). Organisational structure should put in place to support people and organisations in their pursuit of better quality. Such measures comprise an extensive variability of tools to plan work activities, gather data, analyse outcomes, monitor progress and solve problems (Bierman et al., 2013:44). Fotopoulos \& Psomas (2009) stated that techniques need to used and focus on improving quality activities in the construction industry. Basu (2004) suggested the statistical techniques of experimental design to optimise process sceneries to decrease scrap or increase yield. Project managers responsible for this frequently look at process implementation, process optimisation, and practical implementation, future systems of the process, process expertise and process design (Kerzner, 2013).

People Involvement: Top management can influence project success by creating an environment where project teams contribute towards success (Van Wyk, 2003) argue that an organisation's success depends increasingly on having opportunities to acquire, meet, collaboration and practicing new skills. This can evidently influence project success. According to Badu \& Owusu-Manu (2011:270), the critical success factor lies in the construction organisations' real commitment to quality improvement and their 
true target of certification, which finally commands the way and depth to which the standards are implemented. Employee involvement and empowerment has been identified as influential in planning of on-site construction process and organisational performance (Windapo \& Cattel, 2013). It is consequently important for workforces to be involved and empowered in construction planning process by, for example, being able to prepare and meet project teams, use of equipment and the skills and knowledge required to do work effectively (Thorpe et al., 1996; Rumane, 2011). Employees should further be able to share resources, schedule project activities and respond to memos and emails to construction senior management (Aigbavboa \& Thwala, 2014:773). It is also important for SME contractors to be committed and involved in the processes of QA implementation at SME led project level.

Factors that Influence Quality Assurance Practices of Construction Projects: A study by Obare et al. (2016:420) point out that the quality cost model evaluation of quality management practices customer focus teamwork employee empowerment education and continuous improvement influenced project success in addition, Fotopoulos \& Psomas (2009) also asserted that performing check-up, analysis, and corrective actions seemed to obtain customer's satisfaction. Martins \& Lewis (2014) indicated that an effective communication system between project team leaders and management is crucial to the success of construction projects. Windapo \& Cattel (2013), postulate that this is generally influenced by alignment of management commitment and subordinate actions. Karna \& Junnonen (2017:154) indicated that effective designers' performance evaluation in construction projects positively influence the success of a project. Jarkas \& Younes (2014:61) stipulated that, in situations where management commitment is to be ineffective, these should be revised, or new control actions be implemented, thus enabling continuous improvement in construction projects. In reviewing literature, a number of studies have criticized the systems of managing quality during construction process (Arditi \& Gunaydin, 1997). It has been recommended that the failure of many road construction projects in South Africa may partially be ascribed to the poor quality of road constructed by SME contractors in the country (Dangalazana \& Newadi, 2005; Statistics South Africa, 2017). Vermeulen et al. (2018) opined that developing key success criteria for rural development initiatives provides a positive contribution to projects.

\section{Methodology}

The purpose of this research was to determine the factors that influence QAPs that can be implemented for construction SMEs to facilitate or inhibit their projects, in order to achieve project success. A quantitative research design was used, in which the use of structured questionnaire surveys enables researchers to generalise their findings from a sample of population. In the questionnaire, seven QAPs (constructs), consisting of 35 measures, were extracted and set as the variables of quality assurances practices SMEs should follow (Pallant, 2013:192). Exploratory Factor Analysis (EFA) was utilised to assess these measured variables in relation to their validity and reliability. Likert scale was utilised, whereby each participant indicated the degree to which they agreed or disagreed with its contents hence emphasising the significance of choosing the desired response (Leedy \& Ormrod, 2014). According to Pallant (2013:192), EFA can be seen as a type of technique that analyses the characteristics (unidimensionality) of each of the defined QAPs (original variables), in order to reduce it to a common score (smaller number of factors) by examining relationships among these quantitative factors. Various data-analysis strategies are available; Kaiser-Meyer-Olkin (KMO) Bartlett's Test of Sphericity was used to determine whether the correlation matrix is an identity matrix stating if the factor model is inappropriate (Tabachnick \& Fidell, 2007).

Sampling Method and Response Rate: Construction SMEs based local municipalities in Mopani District Municipality constituted the study's population. A total of 160 questionnaires were returned, representing a $64 \%$ response rate of the 250 questionnaires distributed. The local office of Road and Public Works from the District were approached to assist with the compilation of the list. After distributing numbers to form sampling frames, the researcher then used a sample random sampling method to randomly select five projects from each of the five sampling frames. This resulted in the selection of 10 projects (from the initial five projects) from each of the Limpopo Local Municipalities of Mopani District Municipality. The sample of $n=160$ participants completed the questionnaire. The sample size table Krejcie \& Morgan (1970:608) recommends a sample size for a population of 500 of 217. This recommendation validates the sample size of 250 as efficient for the population of 160 . The people contacted for the questionnaires are in the know of the past and current SME projects in the South African construction industry. They were authorized by their organizations to participate in the study as they 
were involved in rural road projects for their respective organisations. However, pseudo numbers and names were used to classify the participants for analysis of data purposes.

Data Collection: Questionnaires were distributed to the prospective respondents who worked on the road construction projects in the local municipalities of Limpopo Province in South Africa, from November 2016 to August 2017. The measuring instrument used in this study included a structured questionnaire survey using Likert-ranking scales as well as open-ended questions to generate qualitative data. Both questionnaires were pre-tested in this study. Questionnaires that are completed by respondents themselves are one of the main instruments for collecting data using a social survey design describe a questionnaire as a method that can be used without direct personal contact with respondents, as these are questionnaires to be completed by respondents. The questionnaires were administered and comprised of two sections. Section A was the biographic profile of the targeted population, namely, age, the highest educational level obtained, number of years' experience in the business and type of ownership in the business. Section B focused on the project characterisation relating to performance variables, namely, road quality construction projects, QAPs, quality management systems and procedures, implementation process, SME contractors as well as CIDB educational needs. In such a situation, anonymity and confidentiality were guaranteed participants were not requested to provide personal details such as names, identity numbers and their physical address.

Section B firstly required that respondents indicated the "level of implementation" achieved at their business for each process and then they rated the importance of each process in achieving a high-quality road construction project. It also demonstrates the design of the section B questionnaire performed a gap analysis between what contractors perceived as a level of implementation versus attaining high-quality standards. This enabled the study to achieve its objectives as well as determining disparities between quality of implementation factor-items and rating of importance factor-items. Section B's criteria were derived as an analytic tool from the factors influencing positive impact of QAPs and then identified and compiled a set of 35 measurable items. It can also be stated that these items were clustered according to the eight (8) Relevance Factors or aspects. Phase B was derived from the review of literature, preliminary study, and, as such, was comprised of a Likert scale development questionnaire. Criteria and critical success aspects of QA processes related to road construction projects. In enquiring questions, researchers have two choices, namely, the questionnaire items may be closed-ended, open-ended, or both (Teddlie \& Tashakkori, 2009:232). It can also be stated that these items were clustered according to the eight (8) Relevance Factors or aspects.

Analysis and Interpretation of the Data: The Statistical Package for the Social Sciences (SPSS) version 22 was used to conduct descriptive, statistical analysis of the data computing the frequencies, mean scores and standard deviations. SPSS was further utilised to determine the feasibility of conducting a factor analysis of the QAPs survey results relating to the QA processes implementation in the construction project delivery. Cronbach's alpha coefficient indicates the average correlation among all the items that make up the scale, in order to determine the reliability of the measuring instrument (Kaiser, 1974). Likewise, exploratory factor analysis (EFA) was used to determine the unidimensionality of the QA road construction processes and their reliability. Reliability was tested using Cronbach's Alpha with a cut-off value of 0.70 (Hair, Black, Anderson \& Tatham, 2014). SPSS indicates that Kaiser-Meyer-Olkin (KMO) Bartlett's Test of Sphericity was used to determine whether the correlation matrix is an identity matrix stating if the factor model is inappropriate (Tabachnick \& Fidell, 2007).

Thus, it measures the index of the appropriateness of factor analysis for overall statistics including each variable related to factor analysis (Field, 2013). Tabachnick and Fidell (2007) further state that the Bartlett method produces scores that are unbiased and that correlate only with their own factor. In this study, KMO and Bartlett's Test was used to determine the correlation between variables as it would guide the study to proceed with factor analysis of data. Kaiser (1994) recommends a bare minimum of 0.5 and that values between 0.5 and 0.7 are mediocre, values between 0.7 and 0.8 are good, values between 0.8 and 0.9 are great and values above 0.9 are superb. The KMO can be calculated for the individual as well as multiple variables and represents the ratio of the squared correlation for individual among variables to the squared partial correlation among variables (Kaiser, 1994). Field (2013), states that the KMO statistic varies between zero and 1 . The factor loadings and other tests conducted gave the Kaiser-Meyer-Olkin (KMO) test 0.767 , suggesting the reliability of factor analysis for this study.

Limitation (s) of the Study: It can be noted that the study was not conducted across South Africa; 
therefore, the findings cannot be generalised.

\section{Results and Discussion}

Respondents' Profile: Table 1 displays the profile of participants and the questionnaire were distributed to 250 SME contractors, of which 160 responded. Approximately 122 were males (76.3\%), while 38 were female $(23.8 \%)$. This response rate implied that road construction was still dominated by males. The highest educational level was a first degree/ diploma (34.4\%), grade 11 or lower (20.0\%), grade 12 (N3) only $(19.4 \%)$, honours/B-Tech $(23.1 \%)$, masters/M-Tech (3.1\%), with $8.1 \%$ having 12 or more years working in road construction. Further to this, data generated from this section indicates how the majority of respondents did not have a Masters' qualification in this study. It is evident from Table 1 that most staff positions were as follows: government officials (41.9\%), QA engineer or architect (15.6\%), client/manager (15.0\%), quantity surveyor (11.3\%), and project administrators (4.4\%).

Table 1: Respondents' Profile

\begin{tabular}{lll}
\hline & Frequency & Percentage \% \\
\hline Gender distribution & 122 & $76.3 \%$ \\
Male & 38 & $23.8 \%$ \\
Female & 160 & $100.0 \%$ \\
Highest educational level & & \\
Grade 11 or lower & 32 & $20.0 \%$ \\
Grade 12 (N3) only & 31 & $19.4 \%$ \\
First degree/Diploma & 55 & $34.4 \%$ \\
Honours/B-Tech & 37 & $23.1 \%$ \\
Masters/M-Tech & 5 & $3.1 \%$ \\
& 160 & $100.0 \%$ \\
Staff position occupied & & \\
Quantity surveyor & 18 & $11.3 \%$ \\
Client/Manager & 24 & $15.0 \%$ \\
Project/Construction Manager & 19 & $11.9 \%$ \\
Architect/QA Engineer & 25 & $15.6 \%$ \\
Project Administrator & 67 & $41.9 \%$ \\
Government Official & 7 & $4.4 \%$ \\
& 160 & $100.0 \%$ \\
Number of years working in construction & & \\
Less than 3 years & 5 & $3.1 \%$ \\
3-6 years & 42 & $26.3 \%$ \\
6-9 years & 37 & $23.1 \%$ \\
9-12 years & 63 & $39.4 \%$ \\
12 or more years of working & 13 & $8.1 \%$ \\
\hline
\end{tabular}

It is evident from Table 2 that most SME-led projects were publicly funded (96.3\%), while only 3.8\% were jointly funded using private and public funds. Conversely, the subcontractors worked for either single trade contractors or the main contractor.

Table 2: SME Type of Funded Project

\begin{tabular}{lll}
\hline & $\mathbf{1 6 0}$ & $\mathbf{1 0 0 . 0 \%}$ \\
\hline SME type of funded project & & \\
Publicly & 154 & $96.3 \%$ \\
Jointly-funded using private and public funds & 6 & $3.8 \%$ \\
& 160 & $100.0 \%$ \\
\hline
\end{tabular}

Table 3 displays the results gathered when participants were asked about how the quality of their projects was rated. The results indicated that most of the projects $(85.0 \%)$ were rated good regarding the quality of road construction. Some participants $(10.6 \%)$ rated their projects as excellently built a few participants $(3.1 \%)$ rated the quality of the road construction as average, while others $(1.3 \%)$ responded that SME road construction organisations built poor roads in a rural community. The participants were also asked how the local authority rated whether the quality road built would improve the quality of life 
in the near future. It can be also seen that the local authority rated $6.3 \%$ of roads as excellent. The results illustrated in Table 2 give rise to the question of why roads were rated as poor or average. One factor emphasised strongly in the study's findings was that there were project planning and control were poor, and most were community members were not directly involved, which led to decreased quality of both road construction and maintenance.

$\mathrm{Xu}$ and Chang (2016) proposed a material-machine-information-human decision integrated system approach for adaptive QC/QA for achieving stiffness and sufficient material density. Measures of central tendency, percentages and frequency distributions were used to analyse non-parametric data such as understanding the respondents' completion time within the projects and rating quality of the road construction for this study.

Quality Assurances Practices Incorporated in the Construction SMEs: The descriptive statistics in Table 3 describe the data that was gathered and illustrate the means, standard deviations, Cronbach level after item deletion, factor loading and rank. It is evident from Table 4 that there were eight practices measuring construction SME role in QA construction processes. To establish convergent and discriminant validity, Spearman's correlation was employed, (Hair et al., 2014). Significant correlations existed among the constructs (refer to Table 4), which demonstrates that convergent validity was within acceptable levels (Field, 2013). Tabachnick and Fidell (2007) further state that, the hypothesis needs to be accepted if correlation statistics fall between -1 and +1 , and that the null hypothesis will determine whether there is a relationship between the two sets of data. In this study, the Kaiser-Meyer-Olkin (KMO) measure of sampling adequacy and Bartlett's Test were used to determine the correlation between variables related through the factor analysis, as reflected in Table 6 (Field, 2013). In establishing the reliability of the measurement scale, Cronbach alpha (a) was calculated. Kaiser (1994) mentions a minimum of 0.5 for the reliability coefficient, and that values between 0.5 and 0.7 are mediocre, values between 0.7 and 0.8 are good, values between 0.8 and 0.9 are great and values above 0.9 are superb. In the current study, internal consistency scores for all the factors examined as well as the entire scale, as displayed in Table 4, ranged from between 0.711 to 0.821 . This states that the scales used were internally consistent.

Table 3: Road Construction Efficiency Aspects Descriptive Statistics

\begin{tabular}{|c|c|c|c|c|c|}
\hline \multicolumn{2}{|c|}{ Eigen Value } & \multicolumn{4}{|c|}{$\begin{array}{l}\text { Overall Cronbach alpha for the entire } \\
\text { scale }=0.802\end{array}$} \\
\hline Item & Action & $\begin{array}{l}\text { Cronbach } \\
\text { level after } \\
\text { deletion }\end{array}$ & $\begin{array}{l}\text { Factor } \\
\text { loading }\end{array}$ & $\begin{array}{l}\text { Number } \\
\text { of items }\end{array}$ & Rank \\
\hline B1 & Level of skills acquisition & 0.819 & 0.827 & 5 & 1 \\
\hline B2 & Project planning and control techniques & 0.821 & 0.819 & 6 & 2 \\
\hline B3 & Project construction design & 0.753 & 0.711 & 8 & 3 \\
\hline B4 & Process implementation and process improvement & 0.744 & 0.777 & 7 & 4 \\
\hline B5 & Financial management & 0.750 & 0.745 & 7 & 5 \\
\hline B6 & Organisational structures & 0.740 & 0.758 & 5 & 6 \\
\hline B7 & Quality standards and measurements & 0.801 & 0.865 & 9 & 7 \\
\hline B8 & Involvement of people & 0.681 & 0.699 & 4 & 8 \\
\hline
\end{tabular}

The purpose of this study was to identify the key aspects influencing poor quality and cost overruns, as well as to determine common operative practices that can control these aspects in rural road construction projects. To achieve this purpose, Spearman's rho coefficient was employed to determine the degree of relationship between these factors. The subsequent results are displayed in Table 4 .

Table 4: Factor Analysis- Relevance Correlation Matrix

\begin{tabular}{|c|c|c|c|c|c|c|c|c|c|}
\hline Factors & B1 & B2 & B3 & B4 & B5 & B6 & B7 & Mean & SD \\
\hline $\begin{array}{lrr}\text { B1. Level } & \text { of } & \text { skill } \\
\text { acquisition } & \text { process } \\
\text { factors } & & \end{array}$ & 1.000 & .827 & .112 & .065 & .057 & .117 & .011 & 4.76 & 0.508 \\
\hline $\begin{array}{l}\text { B2. Project planning \& } \\
\text { control techniques }\end{array}$ & .827 & 1.000 & . 184 & . 110 & .066 & 163 & .048 & 4.72 & 0.574 \\
\hline $\begin{array}{l}\text { B3. Project construction } \\
\text { design }\end{array}$ & .112 & .184 & 1.000 & 818 & 679 & .708 & .430 & 4.05 & 0.431 \\
\hline Process & .065 & .110 & .818 & 1.000 & 867 & .827 & .460 & 4.01 & 0.427 \\
\hline
\end{tabular}




\begin{tabular}{|c|c|c|c|c|c|c|c|c|c|}
\hline \multicolumn{10}{|l|}{$\begin{array}{l}\text { implementation and } \\
\text { process improvement }\end{array}$} \\
\hline $\begin{array}{ll}\text { B5. } & \text { Financial } \\
\text { management } & \end{array}$ & .057 & .066 & .679 & .867 & 1.000 & .809 & .491 & 3.95 & 0.460 \\
\hline $\begin{array}{l}\text { B6. Organisational } \\
\text { structures and } \\
\text { involvement of people }\end{array}$ & .117 & 163 & .708 & .827 & .809 & 1.000 & .500 & 3.93 & 0.464 \\
\hline $\begin{array}{l}\text { B7. Quality standards and } \\
\text { measurements }\end{array}$ & .011 & .048 & .430 & .460 & .491 & .500 & 1.000 & 3.86 & 0.581 \\
\hline
\end{tabular}

(1) level of skill acquisition process factors; (2) project planning \& control techniques; (3) project construction design; (4) process implementation; (5) financial management skills; (6) quality standards; (7) organisational structures; and (8) involvement of people.

Table 5 shows that the mean scores for the factors ranged between 3.86 and 4.76, with standard deviations of 4.27 and 0.581 , which indicated that the Critical Aspects were moderate to very important. These scores reveal a substantial tendency towards the 'agree' position on the Likert scale. The mean is greater than the cut-off of 2.5 (refer to Table 5), reflecting positive sub-factors related to implementing the effectiveness of road construction. This suggests that respondents were largely in agreement with the extent to which these factors of QA process affected implementation (Field, 2013). It is evident from the data that there is a gap between the applications of quality standards, process implementation and improvements of road quality assurance processes. The significance in the results showed that respondents accepted all road construction effectiveness aspects to be relevant when considering the QA processes implementation. As indicated in Table 5, there was sufficient reliability of the seven items, since the Cronbach alpha $(\alpha)$ was greater than 0.7 , meaning that there was a strong relationship between the implementation of QA processes and the effectiveness of road construction SME-led projects. The KMO and Bartlett's test statistics were used to measure the sampling adequacy and appropriateness of the factor analysis and inclusive statistics for each item relating to the factor analysis, and in determining the correlation between items, as shown in Table 5 (Field, 2013).

Table 5: KMO and Bartlett's Test

\begin{tabular}{lll}
\hline KMO and Bartlett's Test & & \\
\hline Kaiser-Meyer-Olkin of Sampling Adequacy & & .728 \\
Bartlett's Test Sphericity & Approx. Chi-Square & 2207.910 \\
& DF & 105 \\
& Sig. & .000 \\
\hline
\end{tabular}

The Kaiser-Meyer-Olkin measure of sampling adequacy was 0.728 and could be regarded as good, demonstrating that the factor analysis was accepted for items under review as depicted in Table 6 . The significant Bartlett's test also supported the strength of the relationship between items and tested whether the null hypothesis of the variables in the population correlation matrix was uncorrelated (Field, 2013). The observed significance level in the test was 0.000 , and was small enough to reject the hypothesis. It was observed that the strength of the relationship between items was strong and gave confidence to proceed in factor analysis on the data.

Exploratory Factor Analysis: The factor analysis was appropriate and displayed values that were above 0.6, which indicated that KMO, Bartlett's degree of freedom (DF) and significance (sig) were also considered satisfactorily for factor analysis as depicted in Table 7. For factor analysis to be appropriate, according to Field (2000:437-8), the variables must be correlated. Factor analysis with principal components was conducted on the level of skill acquisition process scale items. All the quality assurance processes related to the effectiveness of road construction projects had 35 items (Quality of Implementation) and 35 items (Rating of Importance), and each was rated on a five-point scale, ranging from ' 1 ' (Very poor) to ' 5 ' (Excellent), and ' 1 ' (Not at all important) to '5' (Extremely important) (see Annexure A). Therefore, the instrument had been tested, validated and developed with a consideration in the context of road construction projects. In this study, reliability analysis was conducted on the questionnaire subscales.

Reliability can defined as the consistency with which a measuring instrument yields a particular result when the entire measured has not changed (Leedy \& Ormrod, 2014:93). A Cronbach's alpha can be described as coefficient of more than 0.7 as signifying reliability and internal consistency. Overall, 
these tests revealed that the dimensions used to measure factors of interest in this study possessed adequate internal stability and validity to provide confidence that they measured what they purported to. In this study, an analysis of variance (ANOVA) was carried out to determine if there was any significance or non-significance in the results of QA processes related to the effectiveness of road construction projects. The eight dimensions of QA processes in the road construction industry, namely, level of the skill acquisition process, planning and control techniques of the project, project construction design, process implementation, financial management skills, quality standards, organisational structures and involvement of people are discussed in Table 7.

Table 6: KMO and Bartlett's Tests: Extracted Factors

\begin{tabular}{|c|c|c|c|c|}
\hline Factor & $\begin{array}{l}\text { KMO measures of } \\
\text { sampling adequacy }\end{array}$ & $\begin{array}{l}\text { Bartlett's } \\
\text { square) test }\end{array}$ & (Chi-DF & Sig \\
\hline Level of skill acquisition process & .728 & 2207.910 & 105 & 0.000 \\
\hline \multicolumn{5}{|c|}{ Project planning and control techniques } \\
\hline \multicolumn{5}{|l|}{ Project construction design } \\
\hline \multicolumn{5}{|l|}{ Process implementation } \\
\hline Financial management skills & .929 & 9494.842 & 595 & 0.000 \\
\hline \multicolumn{5}{|l|}{ Quality standards } \\
\hline Organisational structures & & & & \\
\hline People involvement & & & & \\
\hline
\end{tabular}

Four factors were extracted (level of skill acquisition process, project planning and control techniques, project construction design, process implementation), and 22 iterations were required. In addition to this, four factors were also extracted (financial management skills, quality standards, organisational structures as well as involvement of people), which were related to quality assurance processes implementation. Pearson's chi-square test proved that SME-led projects did not implement QA processes in the road construction projects. This result indicated that there was no statistical difference between the percentages of the SME-led projects implementing processes of quality assurance in the local municipalities in the road construction projects, which could be termed as a positive moderate correlation at the given levels whereby $\mathrm{p}<.000$ for all eight scales were measured.

Table 6 indicates sufficient reliability on the eight coefficients. This means there was a strong relationship between the variables used in SME-led projects related to road construction projects since the Cronbach was 70, which was advantageous. As a significant positive relationship exists, therefore, there was support for this study question. The factor-loading matrix for the implementation of Quality Assurance (QA) processes and effectiveness of road construction are displayed in Table 7. All variables loaded were above 0.30 , in accordance with specifications used as a cut-off basis. The naming of factors is a subjective process and one should always examine the variables that load highly on a factor rather than relying on the name provided by someone else. In order to name the factor, loadings, as well as constituent items for a specific factor, were examined. Seven visible factors were identified.

Table 7: Factor-Loading Matrix for Implementation of QA Processes and Construction SMEs

\begin{tabular}{lll}
\hline Factor & $\begin{array}{l}\text { QA processes implementation and effectiveness of road } \\
\text { construction }\end{array}$ & $\begin{array}{l}\text { Factor } \\
\text { loading }\end{array}$ \\
\hline & Every stakeholder becomes involved during the planning process & 0.846 \\
& Stakeholder approval of the work package is facilitated & 0.937 \\
$\begin{array}{l}\text { Project planning } \\
\text { and } \\
\text { techniques }\end{array}$ & $\begin{array}{l}\text { All stakeholders receive the project document during the planning } \\
\text { phase }\end{array}$ & 0.923 \\
& $\begin{array}{l}\text { Community provides input on costs and resources for the project } \\
\text { Project manager provide work breakdown detail using } \\
\text { computer/software }\end{array}$ & 0.918 \\
\end{tabular}


Formal system of record-keeping is used for projects

Project scope is designed to adopt technology relating QA processes for road construction

0.765

Scope of work or specification supports the reporting of mistakes by Project design the project team

0.852

construction

Process

implementation

Unforeseen and/-or different geotechnical conditions are described during the construction design

Design of road construction is formally reviewed

Implementation of QA processes is part of the organisation's vision, present and future systems, and process architecture

Practical implementation of the process follows established protocols

0.863

Payments or processing time for tax exemption are properly completed according to the initial agreement

Contractor's establishment costs are evaluated wisely to minimize delays in interim payments

Financial

Costs are re-estimated and/or incorporated when there are changes management skills on the project

All pricing/incentives of services rendered by contractors/consultants are approved and monitored by the fund management

Financial difficulties faced by the contractor are identified and managed on the project according to procedures

Every survey team adheres to a standard set of guidelines on survey implementation

QA procedures are applied to describe monitoring of survey implementation in actual settings

Quality standards

Evaluation of the QA process is visible throughout the survey implementation

Quality control of construction work is conducted by supervising, monitoring, inspections and evaluations

Defective work is reworked or improved prior to approval by the supervisor

Organisation improves the execution of strategies and plans through formal structure e.g. meetings

Organisational structure is aligned with QA processes

0.865

0.953

0.953

0.875

0.848

Organisational structures

People Involvement
Planning, leading and control are facilitated effectively to ensure successful implementation of tasks

Quality of the road is defined, established and controlled at both strategic a process/ operational levels

Customer feedback systems are in place to link all business process related communication

0.865

0.758

Workforce has been given the schedules for projects

0.903 
The result in Table 7 indicates that, the stakeholders in the South African construction use criteria such as (a) project planning and control techniques, (b) project design construction, (c) process implementation, (d) quality standards, (e) people involvement, and (f) organisational structures. This is even important when the singularity and the context under study are not easily divided (Windapo \& Cattel, 2013). Furthermore, through this study approach, someone can identify links between method and theory (Fotopoulos \& Psomas, 2009). Successful implementation of a QAPs requires effective project planning and control techniques, as well as continuous improvement of the project design construction at all levels of an organisation (Construction Industry Development Board (CIDB), 2012). The results of this study show that there are some misunderstandings by the construction SME managers regarding the role of people involvement for rural road projects (Vermeulen et al., 2018). As noted in the literature, SME construction organisations are less able to deal with 'disclosures' in the global economy and are, consequently, most vulnerable. Unless local contractors raise their performance standards relative to foreign competitors, the current situation will deteriorate (Aigbavboa \& Thwala, 2014:712).

Despite the amount of SME contractor's activity available, South Africa still does not perform well when compared to other countries around the globe (Construction Industry Development Board (CIDB), 2012; Tshivhase \& Worku, 2012:41; George, 2016:23). In a similar vein, Freeman-Bell \& Balkwill (1996) stated organisational actors to take better decisions and improve performance. Current on, going research in the area of construction project has indicated strong evidence that people involvement issues, such as customer feedback systems linking all business process regarding communication and project objectives shared with all role players, are determinant factors in contributing to the successful implementation and effectiveness of QAPs is connecting to road construction (Rumane, 2011). All of the above studies concluded that QAPs implementation challenges arose to due to insufficient workforce training. There were no studies that evaluated several training methods or quantified to what degree QAPs implementation were attributable to training. The various implementation and effectiveness indicators were all loaded on one factor, which was labelled level of skill acquisition process. This one factor solution had an eigenvalue of 4.633 and explained 69.679 per cent of the variance. The rotated factor loadings varied between 0.745 and 0.914 for this factor and are displayed in Table 8.

Table 8: Exploratory Factor Analysis

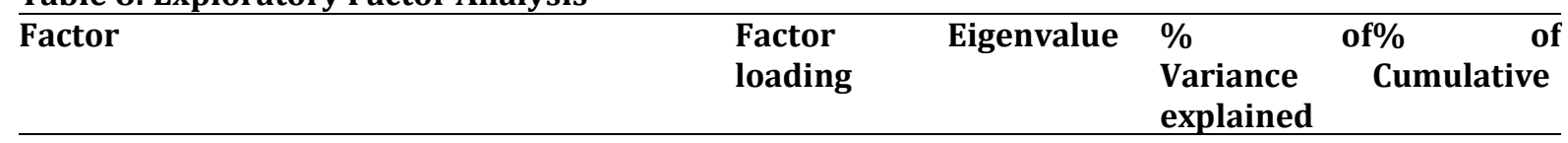

\section{1-Factor}

$\begin{array}{llll}\text { Up-to-date training is provided for employees } & 0.827 & 4.633 & 69.679\end{array}$

69.679

Management commitment to providing QA/QC0.914 training

High level of satisfaction with the training 0.895 programme

Skills development in different roles/ areas $\quad 0.840$

Management facilitates new employees learning 0.745 new skills

Eigenvalue: An eigenvalue represents the amount of variance related to the factor. This view is supported by Hair et al. (1998), who state that only factors above 1.0 are retained and other factors with eigenvalues of less than 1.0 should not be included in the measurement model. In this study, the principal axis factoring indicated the presence of one factor with eigenvalue exceeding 1.0, accounting for $69,68 \%$ of the variance, which was acceptable (Black \& Porter, 1996). Table 8 illustrates item statistics that can be used by a construction organisation to determine if the service meets its organisational goals and if it satisfies aspects such as planning process, skill acquisition, construction design, process implementation, organisational structure, quality requirements and people involvement. Furthermore, to justify these statements, these QAPs should be validated in a national study in order to ensure that they positively influence the successful delivery of road construction projects. 


\section{Conclusions and Recommendations}

In this study, the quality assurance practices of construction SMEs relating local governments of the Limpopo Province (South Africa) were analysed via a questionnaire created from a suitable context based on the Road Quality paradigm. The main conclusion to be drawn from this study is that there seven (7) QAPs to considered by SME contractors and local government managers that seek to identify and establish a road construction project effectively. These seven (7) critical aspects are indicated as latent constructs of the various individual areas identified in this study. Hence, this study concludes that the QAPs that should be considered by the SMEs contractors are (1) level of skill acquisition process factors; (2) project planning \& control techniques; (3) project construction design; (4) process implementation \& process improvement; (5) financial management skills; (6) organisational structures and involvement of people; (7) quality standards and measures. This finding seems to support similar findings by Gotzamani \& Tsiotras (2001) that argues in favour of an appropriate quality standards contributing towards total quality management with technical approaches that can facilitate QAPs in the construction industry. Research literature reviewed highlights that identifying and establishing the impact of QA processes is the new paradigm in running construction projects within the South Africa construction industry, and attention should be given to the way in which its process are assigned, designed, implemented and maintained (George, 2016). For SME construction organisations to improve their road construction projects, owners or managers and their workforces need to implement QA processes effectively throughout the survey implementation.

They need to simultaneously monitor, inspect and evaluate QA at both strategic and operational or process levels. Finally, clear targets for SME construction projects (see Table 8) is confirmed in the one out of seven factors as important aspect for QAPs implementation, which also confirmed by the existing literature (Kerzner, 2013; Rumane, 2011; Olawale \& Sun, 2015; Obare et al., 2016; Panuwatwanich \& Nguyen, 2017). Nevertheless, this study identified six other factors that seem to be equally significant in QAPs implementation. The results evidently indicated that quality of implementation leads to business growth, decrease of poor quality and improved customer satisfaction. In defining, analysing, implementing and evaluation processes of quality as well as effectiveness of road construction, the relationship between senior managers, consultants, workforces and customers remained significant for the success of the business. One major practical subject that has hampered road construction projects for many years is the unpredictability in project construction designs, thus creating impediments when implementing QA processes to the industry. Practical QA guidance for construction SMEs must be properly implemented and used efficiently. Quality improvement workshops must be provided for the required exceptional quality control of construction. Awareness, compliance and selfless adherence to quality standards must be measured regularly (Bierman et al., 2013; Martin \& Lewis, 2014). Quality systems and standards need to be adopted in a way that will enable the organisation to meet its clients' necessities (Honnakker et al., 2010). The study identifies critical core aspects contributing to practising and improving SMEs contractors' performance.

It also highlights what must be improved in relation to SMEs contractors, plans, systems, quality of implementation and organisational structure. The establishment of classy construction, analysis and QA processes using up-to-date scientific achievements are important in the construction project. Communicating effectively internally and externally can have positive impacts on the road quality building even in extreme conditions, reducing the whole life cycle costs of road re-engineering, and consequently, minimal traffic disruption. A good understanding of the impact of road construction SMEs in implementing successful quality assurance process and aligning organisational structures with QA processes in the local government construction as well as difficulties faces by SME road construction projects or municipal managers in South Africa was clearly identified and discussed in detail. The study recommends that SMEs contractors should ensure that quality of rural road infrastructure is implemented and that service quality measures in order to enhance the quality of roads that the municipality is providing in the local communities. The CIDB is main professional body of road construction projects in South Africa, thus public and private Chief Executives Officers (CEOs) and project managers/administrators need to understand the importance of quality through the practice of evidenceroad infrastructure. The project manager of a rural road project who wishes to assure and implement robust quality road infrastructure according to the processes of quality management should concentrate carefully on the seven critical aspects identified above. Project managers should first ensure that the SME contractors' motivation for measuring the service quality is internally oriented, rather than being externally oriented. 
Further Areas of Research: Project managers in the rural road network infrastructure should perform check-ups, inquiries and applying remedial activities to enhance customers' satisfaction that would bring long-term success and business certainty for the organisations (Bierman et al., 2013). It is important for municipal CEOs and project managers to know and understand how users and local community perceive the quality of the rural road construction projects as well as the service elements. Further study could determine that these reliable and valid QAPs can be used to successfully quality of roads infrastructure in construction projects undertaken by construction SMEs. However, study recommends research involving the private sector in sponsoring rural road construction projects through public-private partnerships. Future studies could employ a more rigid research methodology to implement sustainable QA process efficiency to achieve an improved road quality task at the local government level. Furthermore, to justify these statements, these QAPs should be validated in a national study in order to ensure that they positively influence the successful delivery of road construction projects. This study can also be conducted in other African countries for comparative purposes.

\section{References}

Ahadzie, D. K., Proverbs, D. G. \& Olomolaiye. (2007). Critical success criteria for mass housing building projects in developing countries. International Journal of Project Management, 34, 806-818.

Aigbavboa, C. O. \& Thwala, W. D. (2014). Challenges faced blacked owned small and medium construction companies: A case study of Nelspruit-Mbombela Municipality, South Africa. Journal of Economics and Behavioural Studies, 6(10), 771-778.

Arditi, D. \& Gunaydin, H. M. (1997). Total quality management in the construction process. International Journal of Project Management, 15(4), 235-243.

Aziz, R. F. \& Abdel-Hakam, A. A. (2016). Exploring delay causes in road construction projects in Egypt. Alexandria Engineering Journal, 55, 1515-1539.

Badu, E. \& Owusu-Manu, D. (2011). An overview of construction activities in Kumasi, in Adarkwa, K.K. (Ed). The Future of the Tree-Towards Development and Growth, 1'st, 270-289.

Basu, R. (2004). Implementing quality: A practical guide to tools and techniques, enabling the power of operational excellence. UK: Thompson.

Bierman, M., Marnewick, A. \& Pretorius, J. H. C. (2013). Productivity management in the South African civil construction industry-factors affecting construction productivity. Journal of the South African Institution of Civil Engineering, 58(3), 37-44.

Construction Industry Development Board (CIDB). (2012). The construction industry as a vehicle for contractor development and transformation.

Dangalazana, T. \& Newadi, M. R. (2005). An exploratory study into the challenges facing the emerging contractors involved in the construction of low cost housing in Wells Estate and Ikamv'elihle Townships in the Nelson Mandela Metropolitan, South Africa. World Congress on Housing: Transforming Housing Environment through Design, 27-30.

Fang, D. \& Wu, H. (2013). Development of a safety climate interaction (SCI) model for construction projects. Safety Science, 57, 138-149.

Field, A. (2013). Discovering statistics using IBM SPSS statistics. $4^{\text {th }}$ Ed. Thousand Oaks, CA. SAGE Publication.

Fotopoulos, C. B. \& Psomas, E. L. (2009). The impact of "soft" and "hard" TQM elements on quality management results. International Journal of Quality \& Reliability Management, 26(2), 150-163.

Freeman-Bell, G. \& Balkwill, J. (1996). Management in engineering: Principles and practice. UK: PrenticeHall.

Gardiner, P. D. (2005). Project Management: A Strategic Planning Approach. UK: Palgrave MacMillan Ltd.

George, H. (2016). Eliciting the financial challenges facing emerging contractors in developing countries using the critical incident technique: A case of South African construction industry. Business and Management Horizons, 4(2), 23-33.

Gotzamani, K. D. \& Tsiotras, G. D. (2001). An empirical study of the ISO 9000 standards' contribution towards total quality management. International Journal of Operations Production Management, 21(10), 1326-1342.

Hair, J. F., Black, W. C., Babin, B. J. \& Anderson, R. L. (2014). Multivariate data analysis. $5^{\text {th }}$ Ed. Upper Saddle River, NJ, USA: Prentice Hall.

Kaiser, H. (1994). An index of factorial simplicity. Psychometrika, 39, 31-36.

Kam, K. J. \& Hamid, A. H. A. (2014). The true motives behind the adoption of QLASSIC- CIS 7:2006. As a quality assurance initiative in construction industry. International Journal of Quality \& Reliability, 32(6), 603-616. 
Honnakker, P., Carayon, P. \& Loushine, T. (2010). Barriers and benefits of quality management in the construction industry: An empirical study. Total Quality Management, 21(2), 953-969.

Kerzner, H. R. (2013). Project management: A systems approach to planning, scheduling, and controlling. New Jersey, USA: John Wiley \& Sons.

Krejcie, R. V. \& Morgan, D. W. (1970). Determining sample size for research activities. Educational and Psychological Measurement, 30(3), 607-610.

Kruger, D., Ramphal, R. \& Maritz, M. (2014). Operations Management. $3^{\text {rd }}$ Ed. Cape Town: Oxford University Press Southern Africa.

Jarkas, A. M. \& Younes, J. H. (2014). Principle factors contributing to construction delays in the State of Qatar. International Journal of Construction Project Management, 6(1), 39-62.

Leedy, P. D. \& Ormrod, J. E. (2014). Practical Research: Planning and Design. 10 ${ }^{\text {th }}$ Ed. UK: Pearson.

Mahmood, S., Ahmed, S. M., Panthi, K. \& Kureshi, N. I. (2010). Determining the cost of poor quality and its impact on productivity and profitability. Built Environment Project and Asset Management, 4(3), 296-311.

Martin, A. \& Lewis, M. (2014). Pinpointing safety leadership factors for safe construction sites in Trinidad and Tobago. Journal of Construction Engineering and Management, 40(2), 040133046.

Mofokeng, G. \& Thwala, W. D. (2012). Mentorship programmes within the Small and Medium Sized Contractor Development Programme: A case study of the Free State Province, South Africa. Journal of Economics and Behavioural Studies, 4(12), 712-722.

Nyakala, K. S., Vermeulen, A., Pretorius, J. H. C. \& Munyai, T. (2017). Implementation of quality assurance practices and effectiveness of the road construction industry: A case of South African local municipalities. Proceedings of the 2017 Global Business and Technology Association Conference, 636-650.

Obare, J. O., Kyalo, D. N., Mulwa, A. S. \& Mbugua, J. (2016). Implementation process of project control systems and performance of rural roads construction project in Kenya: Role of project team experience diversity. European Scientific Journal, 12(29), 408-422.

Olawale, Y. \& Sun, M. (2015). Construction project control in the UK: Current practice, existing problems, and recommendations for future improvement. International Journal of Project Management, 33, 623-637.

Pallant, J. (2013). SPSS, Survival manual: A step-by-step guide to data analysis using IBM, SPSS. $5^{\text {th }}$ ed. London: Allen \& Unwin.

Panuwatwanich, K. \& Nguyen, T. T. (2017). Influence of organisational culture on total quality management implementation and firm performance: Evidence from the Vietnamese construction industry. Management and Production Engineering Review, 8(1), 5-15.

Rumane, R. J. (2011). Quality management in construction projects. CRC Press Taylor \& Francis Group, LCC.

Statistics South Africa. (2017). Statistical release manufacturing: Production and sales (Preliminary) April 2017.

Tabachnick, B. G. \& Fidell, L. S. (2007). Using multivariate statistics. $5^{\text {th }}$ Ed. Hillside, NS: Erlbaum.

Teddlie, C. \& Tashakkori, A. (2003). Handbook of Mixed Methods in social \& behavioural research. SAGE Publications International Educational and Professor Publisher Thousand Oaks. London. New Delhi.

Thorpe, B., Summer, P. \& Duncan, J. (1996). Quality Assurance in Construction. Surrey, UK: Gower Publishing Ltd.

Tshivhase, L. \& Worku, Z. (2012). Barriers toward the development of emerging contractors in the Limpopo Province. African Journal of Science, Technology, Innovation and Development, 4(1), 4162.

Van Wyk, L. (2003). A review of the South African construction industry: Economic, regulatory and public sector capacity influences on the construction industry. Pretoria: CSIR.

Vermeulen, A., Nyakala, K. S. \& Pretorius, J. H. C. (2018). Development of a road quality assurance measurement tool in construction projects. Proceedings of the 2018 International Conference on Management of Technology (2018 IAMOT). Birmingham, England, 22-26, 1-14.

Windapo, A. O. \& Cattel, K. (2013). The South African Construction Industry: Perceptions of key challenges facing its performance, development and growth. Journal of Construction in Developing Countries, 18(2), 65-79. 